\title{
Sensitivity and specificity of cell block method of transthoracic fine needle aspiration in diagnosis of lung cancer
}

\author{
Yusup Subagio Sutanto ${ }^{1 *}$, Nur Santi ${ }^{1}$, Brian Wasita ${ }^{1}$, Ana Rima ${ }^{1}$, \\ and Hendra Kurniawan ${ }^{1}$
}

\begin{abstract}
\section{BACKGROUND}

Lung cancer is still the main cause of cancer deaths. The high lung cancer mortality rate is caused by a diagnosis factor or therapy selection. The cell block cytology technique using fine needle aspiration (FNA) samples can provide immunocytochemical material that plays an important role in the differential diagnosis of lung cancer subtypes and in determining immunotherapy administration. This study aimed to determine the sensitivity and specificity of transthoracic FNA (TTFNA) cell block cytology in comparison with bronchial washing smears and TTFNA smears in diagnosing lung cancer.
\end{abstract}

\section{METHODS}

This was a cross-sectional diagnostic study involving 26 subjects. All subjects had undergone bronchial washing and CT scan-guided fine needle aspiration followed by cell block preparation. Both direct FNA smears and cell blocks are useful in the diagnostic work-up of patients. Comparative statistical analysis of TTFNA cell block versus bronchial washing smear and TTFNA smear cytology was carried out using the McNemar test.

\section{RESULTS}

Lung cancer was found in 15 patients (57.7\%) using the TTFNA cell block technique. The sensitivity and specificity of the TTFNA cell block technique were $85.7 \%$ and $75 \%$, respectively. There was no difference in the positivity value between TTFNA cell block technique of bronchial wash smear technique, and TTFNA smear on lung cancer diagnosis $(\mathrm{p}>0.05)$.

\section{CONCLUSIONS}

Transthoracic fine-needle aspiration in combination with the cell block technique has good sensitivity and specificity. The TTFNA can be used for immunocytochemical examinations in lung cancer diagnosis and therapy. This approach is valuable for providing individualized treatment and prognostic evaluations.

Keywords: Bronchial washing, cell block, lung cancer, smear, TTFNA
${ }^{1}$ Department of Pulmonology and

Respiratory Medicine

Faculty of Medicine,

Sebelas Maret University /

Dr. Moewardi General Hospital

Surakarta

\section{*Correspondence:}

Yusup Subagio Sutanto

Department of Pulmonology and

Respiratory Medicine,

Faculty of Medicine,

Sebelas Maret University Surakarta,

Indonesia/Dr. Moewardi General

Hospital Surakarta

RSUD Dr. Moewardi Gedung A lt. II

Jl. Kolonel Sutarto No.132, Jebres,

Surakarta, Jawa Tengah 57126

Email:dr_yusupsubagio@yahoo.com

Mobile: +62811284165

ORCID ID: 0000-0001-9392-7603

Date of first submission, January 11 , 2021

Date of final revised submission, July 20, 2021

Date of acceptance, July 26, 2021

This open access article is distributed under a Creative Commons AttributionNon Commercial-Share Alike 4.0 International License

Cite this article as: Sutanto YS, Santi N, Wasita B, Rima A, Kurniawan H. Sensitivity and specificity of cell block method of transthoracic fine needle aspiration in diagnosis of lung cancer. Univ Med 2021;40:130-7. doi: 10.18051/ UnivMed.2021. v40.133-140. 


\section{INTRODUCTION}

The separation of small cell lung cancer and non-small cell lung cancer is no longer based only on morphological differences, but also on immunohistochemical and molecular characterization. ${ }^{(1)}$ Cell-block cytology using fine-needle aspiration (FNA) samples is an immunocytochemical method which plays an important role in the differential diagnosis of lung cancer subtypes. According to the 2015 WHO classification, immunocytochemistry is recommended for many non-small cell lung cancers (NSCLC) that cannot be classified as squamous cell carcinoma or adenocarcinoma based on morphology alone. Immunocytochemistry is also used to distinguish primary and metastatic lung tumors that are difficult to differentiate based solely on smear cytology. ${ }^{(2)}$

The role of cell block cytology is in the diagnosis of lung cancer and in determining the administration of immunotherapy, which is currently growing rapidly. Cell blocks are similar to conventional tissue paraffin blocks in pathology but consist of cells found in tissue fluids such as bronchial washings or fine needle aspirates. Several studies have evaluated the role of cell block cytology as a starting material for the evaluation of programmed death-ligand 1 (PDL1) expression. The study by Malapelle et al. ${ }^{(3)}$ looked at the role of cytology in comparison with histology for the evaluation of PD-L1 expression. The results of the study provide evidence of the feasibility of evaluating PD-L1 expression in cell blocks in clinical practice, as well as of the role of cell blocks in evaluating epidermal growth factor receptor (EGFR), anaplastic lymphoma kinase (ALK) and ROS proto-oncogene 1 (ROS1). Cell blocks of bronchial washings had a higher yield than conventional smears. Increased yield was also noted when cell blocks of bronchial washings were combined with biopsy and compared to conventional bronchial washings combined with biopsy. ${ }^{(4)}$
Cytological techniques such as bronchoalveolar lavage or washing (BAL), bronchial brushing (BB) and fine needle aspiration cytology (FNAC) can help diagnose lung malignancies early. For lung cancer diagnosis, FNAC is the most effective of the three techniques. ${ }^{(5)}$ The limited material available for adjuvant diagnostic studies is one of the limitations of conventional fine needle aspiration (FNA). ${ }^{(6)}$ In the current development of immunotherapy, cell blocks can provide immunocytochemical material. The present study investigates the importance of the cell block method in the diagnosis and therapy of lung cancer. ${ }^{(7-9)}$ The aim of this study was to determine the sensitivity and specificity of transthoracic FNA (TTFNA) cell block cytology in comparison with bronchial washing smears and TTFNA smears in diagnosing lung

\section{METHODS}

\section{Research design}

This was a cross-sectional study of diagnostic tests and was conducted at RSUD Dr Moewardi Hospital, Surakarta, from September to December 2018.

\section{Research subjects}

The research sample consisted of patients with suspected lung cancer who underwent treatment. The sampling method used consecutive sampling with a sample size of 26 patients meeting the inclusion and exclusion criteria. The inclusion criteria were patients aged above 18 years, thorax multi-slice computer tomography (MSCT) scans showing an image of lung tumors with peripheral lesions to be followed by TTFNA and bronchoscopy procedures. Exclusion criteria were patients with lung tumors with symptoms of acute infection, pregnancy, history of chemotherapy, radiotherapy, and massive hemoptysis. Discontinuation criteria were patients refusing bronchoscopy and TTFNA and withdrawing. 


\section{Measurements}

The study subjects' characteristics were age, gender, smoking history, body mass index (BMI), type of lesion on bronchoscopy, and type of lung cancer histology. BMI was calculated as weight in kilograms divided by height in meters squared. The following categories were used: low BMI group (BMI $<18.5 \mathrm{~kg} / \mathrm{m} 2$ ), normal BMI group $(\mathrm{BMI}=18.5-24.0 \mathrm{~kg} / \mathrm{m} 2)$ and high BMI group (BMI>24.0 kg/m2).

\section{Histology}

Both direct FNA smears and cell blocks are useful in the diagnostic work-up of patients. All cytological specimens were prepared according to the standard processing protocol in our laboratory. The Papanicolaou (PAP) stain was used for wet fixed smears and the Diff Quik stain for air dried smears.

\section{Statistical analysis}

The data were analyzed using SPSS 21 for Windows. The basic data were processed descriptively and presented as a distribution of frequencies and percentages. Sensitivity, specificity, positive predictive values and negative predictive values were presented in $2 \times 2$ tables. Comparative statistical analysis of TTFNA cell block versus bronchial washing smear and TTFNA smear cytology was carried out using the McNemar test. A p-value $<0.05$ was deemed statistically significant.

\section{Ethical clearance}

This research received approval for ethical clearance from the Faculty of Medicine, Sebelas Maret University, Surakarta, under No. 687/IX/ HREC/2018.

\section{RESULTS}

The majority of patients were in the age group of over 40 years $(80.8 \%)$. The proportions of males and females was $14(53.8 \%)$ and 12 (46.2\%), respectively. Smoking history was obtained in $14(53.8 \%)$ subjects. The majority of subjects with low BMI was $13(50.0 \%)$. The most common type of lesion was compression stenosis, found in $14(53.8 \%)$ subjects. The most common histological types in this study were adenocarcinoma in $11(64.7 \%)$ subjects and high grade neuroendocrine tumors in 5 (29.4\%) subjects. The TTFNA cell block technique yielded $9(52.2 \%)$ subjects with adenocarcinoma, 5 $(29.4 \%)$ with high grade neuroendocrine, and 1 (5.9\%) patient with adeno-squamous carcinoma (Table 1).

\section{Sensitivity and specificity of TTFNA Cell- block examination}

The results showed that 12 (46.15\%) subjects had positive results in both TTFNA cell block tests and TTFNA smears and bronchial washing smears. Positive TTFNA cell block test results with negative bronchial smears and TTFNA smears were found in $3(11.5 \%)$ subjects. Negative TTFNA-cell block examination with positive bronchial washing smears and TTFNA smears was found in $2(7.7 \%)$ subjects. Negative TTFNA cell block results with negative bronchial washing smears and negative TTFNA smears was found in $9(34.6 \%)$ subjects. The sensitivity of the TTFNA cell block technique for bronchial washing smears and TTFNA smears was $85.7 \%$ while the specificity was $75 \%$. The positive predictive value (PPV) was $80.0 \%$ and the negative predictive value (NPV) was $81.8 \%$ (Table 2).

\section{The value of TTFNA cell block positivity for bronchial smear cytology and TTFNA smears}

The difference in the value of TTFNA cell block positivity for bronchial smears and TTFNA smears in the diagnosis of lung cancer was calculated using the McNemar test, which showed no significant difference in the positivity value of the TTFNA cell block technique for bronchial washing smears and TTFNA smears in lung cancer diagnosis $(\mathrm{p}>0.05)$ (Table 3 ). 
Table 1. Characteristics of research subjects $(n=26)$

\begin{tabular}{|c|c|c|c|c|c|}
\hline \multirow{2}{*}{ Characteristics } & \multirow{2}{*}{$\begin{array}{c}\text { Number of } \\
\text { subjects } \\
\text { n (\%) }\end{array}$} & \multirow{2}{*}{$\begin{array}{c}\begin{array}{c}\text { Bronchial } \\
\text { washing }\end{array} \\
\begin{array}{c}\text { Smear } \\
(+) \mathbf{n}(\%)\end{array} \\
\end{array}$} & \multicolumn{2}{|c|}{ TTFNA } & \multirow{2}{*}{$\begin{array}{c}\text { Total lung } \\
\text { cancer } \\
\text { patients }\end{array}$} \\
\hline & & & $\begin{array}{c}\text { Smear } \\
(+) \text { n }(\%)\end{array}$ & $\begin{array}{r}\text { Cell block } \\
(+) \text { n }(\%)\end{array}$ & \\
\hline Total & 26 & $4(15.4)$ & $14(53.8)$ & $15(57.7)$ & $17(65.3)$ \\
\hline \multicolumn{6}{|l|}{ Age (years) } \\
\hline$<40$ & $5(19.2)$ & & & & $3(17.6)$ \\
\hline$\geq 40$ & $21(80.8)$ & & & & $14(82.4)$ \\
\hline \multicolumn{6}{|l|}{ Gender } \\
\hline Male & $14(53.8)$ & $2(7.7)$ & $7(26.9)$ & $9(34.6)$ & $10(58.8)$ \\
\hline Female & $12(46.2)$ & $2(7.7)$ & $7(26.9)$ & $6(23.1)$ & $7(41.2)$ \\
\hline \multicolumn{6}{|l|}{ Smoking history } \\
\hline Yes & $14(53.8)$ & $2(7.7)$ & $7(26.9)$ & $9(34.6)$ & $10(58.8)$ \\
\hline Not & $12(46.2)$ & $2(7.7)$ & $7(26.9)$ & $6(23.1)$ & $7(41.2)$ \\
\hline \multicolumn{6}{|l|}{ Body mass index } \\
\hline Normal & $11(42.3)$ & $2(7.7)$ & $5(19.2)$ & $5(19.2)$ & $6(35.2)$ \\
\hline Underweight & $13(50.0)$ & $1(3.8)$ & $8(30.8)$ & $9(34.6)$ & $10(58.9)$ \\
\hline Overweight & $1(3.8)$ & $1(3.8)$ & $1(3.8)$ & $1(3.8)$ & $1(5.9)$ \\
\hline Obesity & $1(3.8)$ & 0 & 0 & 0 & 0 \\
\hline \multicolumn{6}{|l|}{$\begin{array}{l}\text { Types of lesions on } \\
\text { bronchoscopy }\end{array}$} \\
\hline Normal & $4(15.4)$ & 0 & $2(7.7)$ & $1(3.8)$ & $2(11.8)$ \\
\hline Compression stenosis & $14(53.8)$ & $1(3.8)$ & $6(23.1)$ & $7(26.9)$ & $8(47.0)$ \\
\hline Infiltrative Stenosis & $1(3.8)$ & 0 & $1(3.8)$ & $1(3.8)$ & $1(5.9)$ \\
\hline Endobronchial mass & $7(31.8)$ & $3(11.5)$ & $5(19.2)$ & $6(23.1)$ & $6(35.3)$ \\
\hline \multicolumn{6}{|l|}{$\begin{array}{l}\text { Histological types of lung } \\
\text { cancer }\end{array}$} \\
\hline Adenocarcinoma & $11(64.7)$ & $3(17.6)$ & $9(52.9)$ & $9(52.2)$ & \\
\hline $\begin{array}{l}\text { High grade neuroendocrine } \\
\text { tumors }\end{array}$ & $5(29.4)$ & $1(5.9)$ & $4(23.5)$ & $5(29.4)$ & \\
\hline Adenosquamous carcinoma & $1(5.9)$ & 0 & $1(5.9)$ & $1(5.9)$ & \\
\hline
\end{tabular}

Abbreviation: TTFNA : transthoracic fine needle aspiration

\section{DISCUSSION}

Lung cancer was found in $57.7 \%$ of subjects using the TTFNA cell block technique. Our study results are almost similar to those of Abdulhameed et al. ${ }^{(10)}$ at the Rizgary teaching hospital, who reported that the prevalence of lung cancer by means of the TTFNA cell block technique was as high as $57.9 \%$. There were more TTFNA cell block subjects than subjects undergoing TTFNA

Table 2. Sensitivity and specificity of TTFNA cell block technique with bronchial washing smear technique and TTFNA smear technique in diagnosing lung cancer

\begin{tabular}{|c|c|c|c|}
\hline \multirow{2}{*}{$\begin{array}{c}\text { TTFNA } \\
\text { cell block technique }\end{array}$} & \multicolumn{2}{|c|}{$\begin{array}{c}\text { Bronchial washing smear technique and } \\
\text { TTFNA smear technique }\end{array}$} & \multirow[t]{2}{*}{ Total } \\
\hline & Positive & Negative & \\
\hline Positive & 12 & 3 & 15 \\
\hline Negative & 2 & 9 & 11 \\
\hline Total & 14 & 12 & 26 \\
\hline Sensitivity & $85.7 \%$ & & \\
\hline Specificity & $75 \%$ & & \\
\hline Positive predictive value (PPV) & $80 \%$ & & \\
\hline Negative predictive value (NPV) & $81.8 \%$ & & \\
\hline
\end{tabular}

Abbreviation: TTFNA : transthoracic fine needle aspiration 
Table 3. McNemar's test for comparing TTFNA cell block technique versus bronchial washing cytology smear technique and TTFNA smear technique in diagnosing lung cancer

\begin{tabular}{lcccc}
\hline \multirow{2}{*}{$\begin{array}{c}\text { TTFNA } \\
\text { cell block technique }\end{array}$} & \multicolumn{2}{c}{$\begin{array}{c}\text { Bronchial washing smear technique } \\
\text { and TTFNA smear technique }\end{array}$} & \multirow{2}{*}{ Total } & p value \\
\cline { 2 - 4 } & Positive & Negative & & 1.000 \\
\hline Positive & 12 & 3 & 11 & \\
Negative & 2 & 9 & 11 & \\
Total & 14 & 12 & 26 & \\
\hline
\end{tabular}

Abbreviation: TTFNA : transthoracic fine needle aspiration

smears. This agrees with the study of Abdulhameed et al. who also found that the proportions of TTFNA cell blocks and smears were $57.9 \%$ and $38.8 \%$, respectively. Their results also showed that bronchial washing smears had a prevalence of $15.4 \%$. Similar results were reported by Vadala et al., ${ }^{(11)}$ in that the diagnosis of lung cancer by bronchial washing smear cytology was found in $36.5 \%$ of cases. The study by Shivakumarswamy et al. ${ }^{(12)}$ in India showed a lower percentage in lung cancer diagnosis, namely $1.85 \%$. Another study by Acharya et al. ${ }^{(13)}$ gave lower results on cytological examination of bronchial mass washing with $9.2 \%$.

Most subjects in our study were over 40 years old $(80.8 \%)$. This is consistent with the risk factors presented by the WHO or the Indonesian Lung Doctors Association (Perhimpuan Dokter Paru Indonesia, PDPI) regarding high risk in male subjects, over 40 years of age, and smokers. ${ }^{(14)}$ Consistent results were shown by Li et al. ${ }^{(15)}$ in Australia who stated that the most subjects (93\%) were in the age group of over 40 years. Similar results were found in the studies by Raiza et al. ${ }^{(16)}$ and Acharya et al. ${ }^{(16)}$ With respect to the subject characteristics, ]this study had a greater proportion of males. Lung cancer accounts for $17 \%$ and $9 \%$ of all cancers in men and women, respectively. ${ }^{(17)}$ However, the incidence of lung cancer in women continues to increase. Another study by Li et al. ${ }^{(15)}$ also showed that the incidence of males was greater at $15.1 \%$, with an increased incidence in females as well.
Subjects diagnosed with lung cancer who had a history of smoking accounted for $53.3 \%$. Smoking history was higher in males than in females. Passive smoking subjects also have risk factors for lung cancer. This is according to the study by Charles et al. ${ }^{(18)}$ where subjects with lower or higher BMI comprised 50.0\%. Lung cancer subjects with low BMI accounted for $53.3 \%$. These results are in line with those of Tomita et al. ${ }^{(19)}$ who found that the proportion of lung cancer patients with a low BMI was $46.3 \%$. This may have been due to the fact that the systemic symptoms of lung cancer that often arise are loss of appetite accompanied by weight loss. The cancer cachexia syndrome is characterized by anorexia and weight loss, resulting in impaired immunity, tissue wasting, and decreased performance status. ${ }^{(20)}$

In this study, the types of lesions found on bronchoscopy were mostly compression stenosis at $53.8 \%$, followed by endobronchial mass, normal picture, and infiltrating stenosis at $31.8 \%, 15.4 \%$, and $3.8 \%$, respectively. Lung cancer found by the TTFNA cell block technique accounted for most of the bronchoscopic lesions, namely compression stenosis at $47 \%$, followed by endobronchial mass at $35.3 \%$, normal picture at $11.8 \%$, and infiltrative stenosis at $5.9 \%$. This contrasts with the study by Acharya et al. ${ }^{(13)}$ which states that compression stenosis and endobronchial mass have the same prevalence, namely $37.7 \%$. This difference may have been caused by the location and size of the mass, which will affect the type of cancer that is found. ${ }^{(13)}$ 
The study results showed that the most frequent histopathological type was adenocarcinoma, $29.4 \%$ from bronchial washing and $52.9 \%$ from TTFNA. In the research of Vivekanand et al. ${ }^{(21)}$ in India, adenocarcinoma was the most diagnosed type of lung cancer. The adenocarcinomas in their study were mostly found in female patients who were passive smokers.

In this study, the TTFNA cell block examination had a good sensitivity of $85.7 \%$ with a specificity of $75 \%$. The results are in accordance with the study by Dong et al. ${ }^{(2)}$ who stated that the sensitivity of the TTFNA cell block technique to establish the diagnosis of lung cancer was $88.7 \%$. The study by Santoshpawar et al. ${ }^{(8)}$ obtained a sensitivity of $89.4 \%$ and a specificity of $96 \%$. Another study by Kakodkar et al. ${ }^{(11)}$ stated that cytological examination with cell blocks increased the positive findings as compared to smears. In their study, the sensitivity and specificity of the TTFNA cell block and smear tests were not too different. Dr. Moewardi Hospital has used TTFNA smears and bronchial washing smears to diagnose lung cancer and has encountered no problems, so the two tests were used as gold standards in the present study.

Lung cancer immunotherapy is currently growing rapidly, and the cell block technique becomes interesting, because one of the immunotherapy requirements is immunohistochemical examination. Immunocytochemistry is a suitable solution for lung cancer immunotherapy, especially in patients who cannot be tested by immunohistochemistry. ${ }^{(3)}$ Takigawa et al. ${ }^{(22)}$ stated that it is important to perform a PD-L1 examination using a good cytological sample if a histological sample is not obtained. Another study by Torous et al. (23) reported no significant difference in the PD-L1 tumor proportion score (TPS) in specimens examined by cell block cytology or histology. Even though the cell block examination and the smear technique have the same sensitivity, the cell block has the advantage of being able to be used as an immunocytochemical sample.
In our study there was no statistically significant difference in the positivity value of the TTFNA cell block technique and the positivity value of cytology of bronchus washing smears and TTFNA smears in diagnosing lung cancer. There has been no study that tested the difference in the positivity of the TTFNA cell block technique and that of the bronchus smear and TTFNA smear techniques. The previous study by Abdulhameed et al. ${ }^{(10)}$ who performed different tests for FNA smear and FNA cell block, found no significant difference in positivity.

The limitation of the present study is that it used the gold standard for lung cancer diagnosis instead of a histopathological examination. This study suggests that it is possible to determine the primary site of malignancy using cell blocks as well as smears. The cell block technique has the added benefit of allowing multiple sections of the same material to be obtained for special stains and immunohistochemistry. ${ }^{(4)}$

\section{CONCLUSIONS}

The TTFNA cell block showed good sensitivity and specificity. There was no difference in the positivity value of the TTFNA cell block examination versus bronchial washing smears and TTFNA smears in lung cancer diagnosis. The cell block technique can be used for immunocytochemical examinations in lung cancer diagnosis and therapy.

\section{CONFLICT OF INTEREST}

The author(s) declared no potential conflicts of interest with respect to the research, authorship, and/or publication of this article.

\section{ACKNOWLEDGEMENTS}

The authors thank all patients who were willing to participate and all who supported this study. We also thank the Director of Dr. Moewardi Hospital Surakarta, for the opportunity to perform this study and collect the data. 


\section{CONTRIBUTORS}

YSS contributed to conceptualization, methodology, and writing the original draft. NS and BW contributed to methodology and data collection and analysis. AR and HR contributed to writing, reviewing, and editing. All authors have read and approved the final manuscript.

\section{REFERENCES}

1. Kossakowski CA, Morresi-HaufA, Schnabel PA, Eberhardt R, Herth FJF, Warth A.. Preparation of cell blocks for lung cancer diagnosis and prediction: protocol and experience of a highvolume center. Respiration 2014;87:432-38.doi: 10.1159/000357068.

2. Dong Z, Li H, Zhou J, Zhang W, Wu C. The value of cell block based on fine needle aspiration for lung cancer diagnosis. J Thorac Dis 2017;9:237582. doi: 10.21037/jtd.2017.07.912017;9(8):2375-82.

3. Malapelle U, Iaccarino A, Rossi A. Cytology versus histology for programmed death-ligand 1 expression evaluation in the landscape of nonsmall cell lung cancer patients selection for immunotherapy. Transl Lung Cancer Res 2018;7(Suppl 3):S221-4. doi: 10.21037/ tlcr.2018.08.09.

4. Sung S, Heymann JJ, Crapanzano JP, et al. Lung cancer cytology and small biopsy specimens: diagnosis, predictive biomarker testing, acquisition, triage, and management. J Am Soc Cytopathol 2020;9:332-45. doi: 10.1016/j.jasc.2020. 04.014.

5. Tomar V, Vijay N, Nuwal P, Dixit R. Comparative study of bronchoalveolar lavage, bronchial brushing, and FNAC in diagnosing malignant neoplasms of lungs. J Cytol 2016;33:210-3. doi: 10.4103/0970-9371.190448.

6. Khan S, Omar T, Michelow P. Effectiveness of the cell block technique in diagnostic cytopathology. J Cytol 2012;29:177-82. doi: 10.4103/0970-9371.101167.

7. Yang W, Jiang H, Khan AN, et al. Transthoracic needle aspiration in solitary pulmonary nodule. Transl Lung Cancer Res 2017;6:76-85. doi: 10.21037/tlcr.2017.02.03.

8. Santoshpawar, Sameer M, Manishaahuja, Amitapatil. Sensitivity and specificity of cell mlock method in diagnosis of lung malignancies. IOSR J Dent Med Sci 2016;15:86-99. doi: 10.9790/ 0853-1504018699.
9. Vural G. Transthoracic fine-needle aspiration biopsy cytology of pulmonary lesions. Euroasia J Math Eng Nat Med Sci 2020;7:55-62. doi: 10.38065/euroasiaorg.214.

10. Abdulhameed T, Omer J, Ali S. Cell blocks histopathology versus FNA cytology in diagnosis of primary malignant lung mass: a comparative study. Zanco J Med Sci 2017;21: 1601-7. doi: 10.15218/zjms.2017.009.

11. Kakodkar UC, Vadala R, Mandrekar S. Utility of cell-block of bronchial washings in diagnosis of lung cancer- a comparative analysis with conventional smear cytology. Clin Diagn Res 2016;10:OC25-8.doi: 10.7860/JCDR/2016/15911. 7634.

12. Shivakumarswamy U, Arakeri SU, Karigowdar MH. Diagnostic utility of the cell block method versus the conventional smear study in pleural fluid cytology. J Cytol 2012;29:11-5. doi: 10.4103/ 0970-9371.93210.

13. Acharya VK, Unnikrishnan B, Shenoy A, Holla R. Utility of various bronchoscopic modalities in lung cancer diagnosis. Bronchoscopy in lung cancer diagnosis. Asian Pac J Cancer Prev 2017;18:1931-6. doi: 10.22034/APJCP.2017.18.7. 1931.

14. Indonesian Lung Doctors Association. Non-small cell carcinoma type lung cancer. Jakarta: PDPI; 2017.p. 1-29.

15. Li M, Sundararajan R. Gender and age analysis of lung cancer in Australia. Gen Med (Los Angel) 2017;5: 299. doi: 10.4172/2327-5146.1000299.

16. Raiza D, Al E. Efficacy of bronchial wash and brush cytology in the diagnosis of lung cancers. Int J Heal Res Mod Integr Med Sci 2014;2:81620.

17. Cheng TD, Cramb SM, Baade PD, Youlden DR, Reid ME NC. The international epidemiology of lung cancer: latest trends, disparities, and tumor characteristics. J Thorac Oncol 2016;1 1:1653-71. doi: 10.1016/j.jtho.2016.05.021.

18. Cruz CSD, Tanoue LT, Matthay RA. Lung cancer: epidemiology, etiology, and prevention. Clin Chest Med 2011;32:605-44. doi: 10.1016/j.ccm. 2011.09.001.

19. Tomita M,Ayabe T, Nakamura K. Low body mass index is an independent predictive factor after surgical resection in patients with non-small cell lung cancer. Asian Pacific J Cancer Prev 2017;18:3353-6. doi: 10.22034/APJCP.2017. 18.12.3353.

20. Jusuf A, Hudoyo A, Andriani R IR. Diagnosis of lung cancer. In: Jusuf A, editor. Basic diagnosis of lung cancer. 1 st ed. Jakarta: UI Publishing; 2017.p.127-68. 
21. Giti R, Hosseinzadeh M. Efficacy of bronchial washing and brushing cytology in the diagnosis of non-neoplastic lung diseases. Acta Med Iran 2017;55:636-41.

22. Takigawa N, Ochi N, Yamane H. Histology versus cytology: PD-L1 testing in non-small cell lung cancer. Transl Lung Cancer Res 2018;7(Suppl 3):S225-7. doi: 10.21037/tlcr.2018.08.08
23. Torous VF, Rangachari D, Gallant BP, Shea M, Costa DB, VanderLaan PA. PD-L1 testing using the clone $22 \mathrm{C} 3$ pharmDx kit for selection of patients with non-small cell lung cancer to receive immune checkpoint inhibitor therapy: are cytology cell blocks a viable option? J Am Soc Cytopathol 2018;7:133-41. doi: 10.1016/j.jasc.2018. 02.003 . 